\title{
Mario Vargas Llosa's the Time of the Hero: Paradox of Military Man
}

\author{
MOHAMMAD SAFAEI \\ School of English, \\ University of Nottingham Malaysia \\ safaeim@hotmail.com
}

\begin{abstract}
Mario Vargas Llosa's The Time of the Hero, originally published in Spanish in 1963, depicts military life and its paradoxes in Leoncio Prado, a military high school that the Peruvian author attended in early 1950s. In this essay, I investigate the paradox of military man in regard to two systems of thought as well as two diverse ontologies. Drawing upon Gilles Deleuze's metaphysics and his collaborative work with Félix Guattari, I explain, in specific, the properties of mass multiplicities versus pack multiplicities and their corresponding relation to the difference between a State army and its inherent war machine. I analyse the paradox of perceptions and praxis that each of these multiplicities is disposed to generate. Despite the military administration's insistence on the development of organized behaviour and authentic identities, Leoncio Prado provokes the formation of packs with their inconceivable practices and modes of becoming that undermine the academy's fundamental tenets. Vargas Llosa demonstrates that the event of becoming which, in this novel, exemplifies resistance against oppressive military norms proceeds along an unpredictable trajectory and culminates in the formation of cells with microfascist sentiments and economy. The emergence of a microfascist cell is a fundamental paradox and ironically the consequence of the military insistence on discipline and submission to authority. In some respects, the radicalization of packs results from initiation rites and other abusive practices that have historically been woven into the fabric of military training.
\end{abstract}

Keywords: fascism; fiction; initiation; Latin America; military

\section{INTRODUCTION}

The Time of the Hero revolves around the appalling death of a cadet in a prestigious military high school in Lima and the endeavours of the military administration to conceal the details of this death to save the school's reputation. The novel, in a broader sense, demonstrates how an immoral society desensitizes its individuals to crime and injustice and how a perverted educational institution reinforces the unethical practices of such a society (Kristal, 1998, p. 42). With its ambience of violence, hypocrisy, and corruption in a military academy, The Time of the Hero presents "the microcosm of Peruvian society under the dictatorship" of its military ruler Manuel Arturo Odría Amoretti (Williams, 2014, p. 132). Considered a "highly critical but convincing portrayal of the Peruvian military" (Martin, 2012, p. 26), the novel also reflects Vargas Llosa's traumatic experience of being a cadet at Leoncio Prado Military Academy from 1950 to 1952 (Ocasio, 2004, p. 117). Even though the book's publication in 1963 initially instigated a public condemnation by the military institution, with protesters burning hundreds of copies of the novel in front of Leoncio Prado (Hart, 2007, p. 208), Vargas Llosa's narrative has been acclaimed for its brilliant depiction of the role of patriarchy and military authority in the lives of a few cadets who have to experience the agonizing incidents of the rite of passage from boyhood to manhood (Castro-Klarén, 1990, p. 21).

One can observe, in the critiques on The Time of the Hero, a recurrent emphasis on the themes of "immorality" (Kristal, 1998, p. 42), "inevitable corruption" (Thornhill, 1982, p. 105), "dissimulation and perversion" (Castro-Klarén, 1990, p. 22). The novel, as such, is typically construed as an "offensive" portrayal of military "ethics" (Williams, 2014, p. 26) and the army's "corrupt culture" (Moraña, 2016, p. 28) within a "corrupt" society (Martin, 2012, p. 28). In this essay, I principally intend to depart from the established approaches to Vargas 
Llosa's narrative and instead explore the tensions in Leoncio Prado in terms of specific modes of becoming and dissidence. To this end, I draw upon Gilles Deleuze and his metaphysics of becoming which establishes the basis of my discussions on the antithetical thoughts and groupings in The Time of the Hero. Deleuze distinguishes two modes of ontology: an ontology of being that relies on common sense and perceives things in terms of their fixed attributes and determinable sense; and an ontology of becoming with its inherent paradox that affirms the state of indeterminateness resulting from opposing properties and directions within an event (Deleuze, 1990, p. 1). Being and becoming, from a Deleuzian perspective, define the dualism of existence, a dualism that differs from the traditional distinction made between the sensible and the intelligible. Becoming, according to this definition, is a concealed and yet rebellious mode of existence. It involves an intrinsically non-commonsensical and protean component that not only contests the relation between Idea and its representation, but reveals the essence of becoming and its paradox of opposing senses and effects (p. 2).

What is chiefly at stake here is that "becomings" should not be construed as "things" in themselves, but as "orientations, directions, entries, and exits" (Deleuze \& Parnet, 2007, p. 2). As becomings involve a way of escape from the dictates of organized thought, Deleuze conceives of becoming as a line of flight with no premeditated departure or destination, suggesting "no terminus from which you set out, none which you arrive at or which you ought to arrive at" (p. 2). Hence, it is crucial to emphasize, at the outset, that the paradox of becoming in a military man does not imply seeking a determinable identity, for 'becoming' cannot entail a resemblance to, or, an identification with something. More specifically, becoming signifies "a relation which includes the opposite within it" (Deleuze, 1994, p. 141). The military administration, in The Time of the Hero, insists on strict abidance by military instructions and requires the cadets to "behave perfectly" as if they are "running on rails" (Vargas Llosa, 2004, p. 304). The paradox of military man, from a Deleuzian perspective, demonstrates how Leoncio Prado induces specific modes of becoming that make cadets move "off the rail" (Deleuze \& Parnet, 2007, p. 40). As a line of flight defines the cracks or the possibility of dissidence or even creative adaptation and recovery within rigidified systems (Guattari, 2011, p. 52), I aim to examine how the military life within the academy provokes diverse lines of flight from the norms and perceptions that the institution strives to enforce on its subjects. Vargas Llosa presents a multifaceted account of life in a military college that, despite its stringent regime of identification, engenders a space for the emergence of internal paradoxes and subversive modes of becoming.

\section{WAR MACHINE AND INITIATION}

The paradox of military man as well as the paradox of cadet life in The Time of the Hero can be explained in regard to the historico-mythical components of the State and political sovereignty. The ancient forms of the State or sovereignty demonstrate a politico-theological convergence between two poles of authority: the king and the priest. The former is a despot who subjugates people and obliges them to comply with his rule; the latter is a jurisprudent that exerts his canonical authority via pacts and agreements. The former is a majestic founder; the latter is a cunning organizer. The existence of the two poles or heads of sovereignty does not imply a binary opposition. On the contrary, they are the complementary components of one machine or assemblage: the State apparatus. The two poles, as such, engender dualistic yet concatenated roles and functions, such as emperor-legislator or conqueror-organizer (Deleuze $\&$ Guattari, 1987, p. 351). The sustainability of the State apparatus or sovereignty necessitates the administration of some form of law enforcement or violence. To subdue vice or social unrest, the State apparatus may employ a variety of instruments, namely, penitentiary houses, wardens, police, jailors, magistrates. War, and hence, the existence of a war machine, is 
extrinsic to the original foundations of the State apparatus. To engage in a war, under any circumstances, the two poles of the State have to deploy a war machine. Nonetheless, this deployment has to presuppose a juridical integration of the war machine as a military institution (p. 352).

The incorporation of the war machine into the State apparatus engenders an elusive paradox. Originally, a war machine is a tribal or nomadic group, residing within a territory which is not dominated by the State regulations. What is noteworthy here is that war, in its nomadic state of existence, is only one of the functions of a war machine. War machines, in their primordial state, "tend much more to be revolutionary, or artistic, rather than military" (Deleuze, 1995, p. 33). Nevertheless, with its being appropriated by the State apparatus and, as a corollary, via its institutionalization as a military body, a war machine is transformed into a regular military institution and is subsequently enforced to assume the administration of war as its only principal mission. As a result, the State army embodies a negative force, that is, a war machine, with an intrinsic potentiality for unruly behaviour, inducing suspicion in political leaders in respect of their military institutions and their potentials for subversive actions (Deleuze \& Guattari, 1987, p. 355).

The State military and a war machine differ from each other in respect of their immanent relation to two types of multiplicities: mass multiplicities and pack multiplicities. Large quantity, unidirectional hierarchy, and divisibility characterize the former. The latter, on the contrary, is confined to a smaller number of members and is distinguishable by its lack of a fixed hierarchization with the possibility of nonmetric metamorphoses for the members. Whereas a mass leader can capitalize on his previous triumphs, the leadership status within a pack is volatile; the leader of a pack is invariably on the verge of losing his leadership status (Deleuze \& Guattari, 1987, p. 33). The military officers, in Vargas Llosa's novel, often conceive of their cadets as an acquiescent population with fixed identities under their unidirectional command. However, this illusion is, at times, shattered by the cadets' disruptive behaviour or nonchalance. When lieutenant Gamboa, the most trustworthy and "model officer" in the academy (Vargas Llosa, 2004, p. 164), requires a group of volunteers, none of the cadets "stepped forward: the cadets looked everywhere except straight ahead" (p. 171). Lieutenant Calzada attributes the cadets' defiance of rules and military discipline to their thinking "like civilians" and complains that they only deteriorate "from bad to worse" (p. 169). One official considers the cadets "a bunch of savages" (p. 186). Another reminds them that they are "in the armed forces and not a menagerie" (p. 262). A non-hierarchized relation in the academy is almost inconceivable and the formation of packs is almost unacknowledged by the military authority, with stringent measures implemented to impose mass multiplicity on the cadets.

Ironically, the enforcement of mass multiplicity on the novices is concurrent with the unpremeditated formation of a pack multiplicity triggered by an initiation process within the barracks where the novice cadets are subject to a series of gratuitous punishments. The spirit of military life, which is recapitulated in the virtues of "obedience, courage, and hard work," is subject to diverse interpretations (Vargas Llosa, 2004, p. 44). Just as the enforcement of "obedience" and resort to "absolute coercion" are fundamental to the structure of power relations in the military (Khoo \& Abdul Hamid, 2019, p. 55), obedience in Leoncio Prado proves vital, often emerging as slavish acquiescence to the demeaning harassment imposed by the cadets of a higher rank. A case in point is Ricardo who is coerced, besides being beaten and soaked with saliva, to lick filth, polish several "pairs of boots," and drink "piss" (Vargas Llosa, 2004, p. 46). The military community has virtually accepted that Third Year, or the lowest ranking, cadets are "the Dogs" (p. 34). The enforcement of this denigrating position on the new students is a part of the initiation rite in the college. As such, not only does Ricardo have to confess that he is "a dog" and "go around on all fours" (p. 45), but he is also enforced to sing "I am a dog" (p. 44). 
Understandably, the critical scholarship on The Time of the Hero often highlights the centrality of beastly vice and its ramifications in Leoncio Prado. The book's Spanish title $L a$ ciudad y los perros, literally meaning 'the city and the dogs', articulates the state of animality within the military school in "juxtaposition with the apparently civilized world of the city outside" (Hart, 2007, p. 207). The novel also exposes "the unfairness of conscription and military service" (Gonzalez-Cueva, 2000, p. 90). Not only does it portray the ineluctable decadence of young people in an ambience of cruelty, hypocrisy, and harassment (Thornhill, 1982, p. 105), but it also demonstrates how a group of officers, mostly deluded by hierarchical promotion and the apparent stability and prestige of their profession, systematically condone the rampant violence and crime within the school (Nunn, 1987, p. 462). Apart from such attitudes toward the portrayal of depravity and beastly demeanour in the novel, one has to realize that initiation is an intrinsic component of warrior societies where the acts of torture and harassment function as mental and physical preparation for the brutality and ordeal the novices have to endure as would-be warriors (Digby, 2014, p. 63). Even though any form of initiation, in a mythological sense as well as in actuality, entails a measure of suffering for the attainment of self-realization (Zandy Ali Pinak \& Lalbakhsh, 2019, p. 42), a magical religious experience lies at the heart of military initiation that profoundly transforms the warrior's mode of being. In other words, military prowess and physical stamina do not suffice in the generation of a warrior. The young warrior must endure the transmutation of his humanity by a fit of pugnacity and terror-striking fury (Eliade, 1958, p. 84).

Whereas the issue of animality in the cadets has been construed sometimes as a stratum of bestial cravings and instincts in human beings (Magnarelli, 1976, p. 39) and sometimes as the aggressiveness and unrestrained sensuality that supposedly overwhelms juvenile people (Gonzalez-Cueva, 2000, p. 92), I intend to probe animality in the light of initiation and the process of becoming-animal, for as Deleuze and Guattari (1987) assert, "A military man does a wolf; a military man does a dog" (p. 34). In The Time of the Hero, a Third Year cadet's confession of being a 'dog' is accompanied, according to the norms of initiation, by his imitating a dog. Under psycho-physiological stress and harassment, the new cadets undergo a crucial transformation. The vestiges of this transformation can be observed in Ricardo when he is imbued with certainty that his entire body is "covered with thick fur" and that his mouth is "a pointed muzzle" (Vargas Llosa, 2004, p. 46). The magical metamorphosis of Ricardo implies, from a Deleuzo-Guattarian perspective, the becoming-dog of the cadet, with this caveat in mind that one does not morph into "a barking molar dog, but by barking, if it is done with enough feeling, with enough necessity and composition," one can emanate "a molecular dog" (Deleuze \& Guattari, 1987, p. 275). Ricardo's becoming-dog marks his entrance into a zone of proximity where the micro-transmutations of an individual in terms of his affections, moods, and functions emerge in opposition to what a human being conventionally represent as a discrete metaphysical genus. In other words, one should not perceive the process of becoming-dog or becoming-wolf in terms of an analogy or a resemblance to a given animal, "for this is becoming-animal in action, the production of the molecular animal" (Deleuze \& Guattari, 1987, p. 275).

Initiation, in many military forces across the globe, is typically "spontaneous, completely unofficial, and often even prohibited and combated by the institutional authority" (Caforio, 2009, p. 96). The Time of the Hero delineates how initiation is an accepted norm in the academy and how its resulting forms of becoming and pack formation ironically undermine the very tenets of the military administration. The formation of packs engenders a set of unofficial yet resilient allegiances with strict rules that transgress the ostensibly rigid norms of military organization in Leoncio Prado. The cadets routinely undergo a variety of harassments and gradually emanate some considerable measure of warrior aggression in their behaviour. Ricardo, derided for his effeminacy and often addressed by his pejorative epithet Slave, 
considers his betrayal of Cava, who stole the exam questions, as the normative practice of vengeance among his peers, and demonstrates to his superior, lieutenant Huarina, that he is "not afraid" of his action's consequences (Vargas Llosa, 2004, p. 126).

It is the acceptance of this novel, albeit fleeting, experience of a molecular becoming that compels Ricardo as well as others in his section to establish a self-defensive pack, the Circle, to terminate an initiation process that usually continues, to the dismay and resentment of the novices, during "a whole month" of confinement to the rigid structure of military life in the academy (Vargas Llosa, 2004, p. 49). No one is exempt from initiation and the latrines are overwhelmed by the sound of "retching" and "vomiting" (p. 47). Even the apparently uninitiated Jaguar, a resilient and vigorous cadet recognized by this name, has to endure punches, revealing signs of bruise on his "chin and cheekbones" (p. 49). What is remarkable is that the cadets, at the outset, perceive their world and their relation to others within a mass multiplicity. Hence, no group attack or resistance is initially launched against the cadets of superior ranks. For instance, Ricardo and an anonymous peer act as dogs and engage in a dog fight, with the latter "barking and frothing at the mouth," biting Ricardo like "a rabid dog" (p. 46). In the same manner, Jaguar and Cava react separately without assisting each other. The Fourth Year students, being exhausted of fighting with Jaguar, permit him to leave the place and begin "initiating" Cava (p. 49). The cadets of a given section in the school are the individuals within a mass, with almost zero ability for dissidence, as they are supposed to obey their superiors and study under the supervision of professional military personnel who propagate military norms. Despite the administration's efforts, the cadets' education is systematized within the space of a former war machine that, by virtue of its very nature, engenders various modes of becoming as well as specific tendencies for the formation of packs.

The Time of the Hero also depicts a number of social groupings or packs outside the academy, with incidents pertaining to the rivalries among gangs of robbers, to the teams of boys who play soccer and disturb the quiet of the neighbourhood, and to the "tightly knit" groups of girls who are "bitterly hostile toward boys" (Vargas Llosa, 2004, p. 65). Yet the Circle, as a grouping with war machine tendencies under the administration of a former war machine, has centrality in the novel and accords insights into the essence of military life, comprised of both mass and pack multiplicities. The Circle, as a pack consisting of the cadets of Section One, encourages its members to retaliate, with vengeful assaults launched surreptitiously and often during the night by the members of the Circle who stalk around like "mask shadows" (p. 50). Via several surprise operations, often planned and organized by Jaguar, the cadets of Section One impair the superior status of their persecutors. They strip a guard naked, injure a few others, and poison "the soup kettles of the Fourth Year" with bags of defecation, making them suffer "dysentery" (p. 50). These "anonymous reprisals" provoke the cadets of the Fourth Year to implement the routine "initiations even more brutally" (p. 50). Moreover, the very centre of the counterattacks, that is the Circle, is soon discovered and dismantled by lieutenant Gamboa and under his threat of discharging the "whole" gang from the academy (p. 52).

The military people have to be physically and psychologically prepared to encounter the challenges of combat zones. In order to survive, they often have to adapt themselves to trauma-laden situations and learn to endure all other "dramatic circumstances that arise in times of war" (Alosman \& Raihanah, 2020, p. 141). From a military perspective, one can conceive of the initiation process in Leoncio Prado as an inalienable component of military training. For not only does it strengthen the emotional connection between the newly recruited individuals and those preceding them in rank, but it also "sublimates simple rules of aggregation that tend to give a semblance of order to the chaos of combat, to the moral and material disorder of armed conflict" (Caforio, 2009, p. 95). We may correspondingly regard military initiation, in contradistinction to the so-called military hazing or the abuse of the lower ranks under the guise 
of initiation, as a positive social process "in the creation and reinforcement of the esprit de corps" (p. 96). From an analogous viewpoint, Gamboa, who can "recite" military regulations "from memory" (Vargas Llosa, 2004, p. 323), conceives of the Circle as the consequence of novice cadets" ignorance about "military life," "team spirit," and the "respect" they owe to their "superiors" (p. 52). From a Deleuzo-Guattarian perspective, the narrative brilliantly portrays how the military authority in Leoncio Prado is engaged in a paradox, for it strives to impose mass multiplicity on a group of cadets who are induced, by the very nature and procedure of initiation and other types of harassment, to form a pack multiplicity to undermine the hierarchized institution where they are supposed to assimilate military norms.

\section{PACK MULTIPLICITY AND MASS MULTIPLICITY}

The structure of military administration in the academy is commensurable with that of a mass multiplicity with its unidirectional organization and command. The colonel, for instance, singles out himself and his status. In the wake of Ricardo's death, an unresolvable "mystery" in the novel (Martin, 2012, p. 27), he emphasizes that the enemies of the academy are seeking an opportunity "to smear us with a thousand lies. Especially me" (Vargas Llosa, 2004, p. 228). Later he reminds his junior officers of how he is "surrounded by enemies" (p. 229). The officers not only obey him as their commander, but also ensure, for instance, that "the largest" wreath in the funeral carries his condolences "card" (p. 227). Mass multiplicity implies also a metric conception that may appear, at first glance, coldblooded cruelty. For instance, the colonel is infuriated that cadets of Section One are "shocked" by the death of their friend Ricardo (p. 229). Based on this metric conception, any fallen soldier or cadet is disposable as well as replaceable. Allegiance is only conceivable between the group and the leader and not among the peer members of a group. As such, the colonel conceives of this sense of camaraderie among the cadets as the consequence of his officer's failure to induce "discipline" (p. 230, emphasis original).

A highly ironical circumstance is that disloyalty among peers is encouraged by the military organization in the college. To put this another way, the mass multiplicity of the military administration is intent upon suppressing pack formations. For instance, whenever a regulation is anonymously transgressed, or, an offence secretly committed, the cadets are not allowed to leave the academy unless they betray the culprit who is definitely one of their friends. As the moment of leaving the school on weekends is the most joyous occasion that a cadet may experience, confinement proves an almost unbearable punishment. This is a lengthy confinement, or, an agonizing separation from the free world outside the academy, that enforces Ricardo to inform against Cava. The administration building, where the colonel's office is located, looms monstrous and "satanic," since it signifies the place "where confinement lists were made" (Vargas Llosa, 2004, p. 307). The cadets are trained to obey the commands during field exercises, not because it is a mark of soldierly deportment or military professionalism, but to avoid a death that gratuitously deprives them of freedom outside the academy, for "the corpses won't get a pass on Saturday and Sunday" (p. 176). Even Gamboa, at times, aspires to be off duty, so that he can relish his "hours of freedom" outside the school (p. 343).

Recognized as the Dogs, the Third Year cadets are subject to a series of harassments. They are coerced, for instance, to drink "mixed cocktails of gun grease, oil, and soap" (Vargas Llosa, 2004, p. 50). From the perspective of the cadets in Section One, the initiation rite in Leoncio Prado is a disgraceful "deal" that has to be retaliated by the Circle's proportionate counterattacks (p. 52). What is striking in regard to the Circle is that its eventual disintegration does not culminate in a reverse direction, that is, in the resumption of a pre-pack identity or existence for an individual cadet. On the contrary, the disintegration of the pack, the so-called 
"big Circle" (p. 57), is conducive to the proliferation of smaller packs. The endeavours of the administration to promote unity among the cadets of Section One during athletic competitions are intimations at the formation of several packs and, consequently, at the heterogeneity of interests and intentions within the section. Surprisingly, the cadets' cooperation in the spirit of a single war machine and their eventual triumph over the cadets of a higher rank appear, to the entire military administration, a flagrant violation of tacit rules. As such, when the cadets of Section One defeat their superiors during athletic competitions, the military commanders unanimously condemn the cadets' brash victory and consider it "a disgrace" for the academy, an obvious "plot" (p. 70), and "a shameful incident" that deserves punishment "from the army point of view" (p. 72). In other words, only superficially do the military authorities encourage the cadets to make their utmost efforts during the competitions. What Lieutenant Huarina, as such, cannot anticipate is the transgression of institutionalized power relations in the academy. In other words, the military administration expects the lower ranks to yield ultimately to the requirements of mass multiplicities and, consequently, to the demands of their superior ranks. The cadets are supposed to combine their efforts only when they are commanded to do so and insofar as their unified struggle does not unsettle the hierarchical structure of the college. The paradox of military man proves more substantial when officer Huarina realizes that the cadets of Section One are prevailing. He addresses the cadets as "animals" (p. 67) and cautions them against the rage and admonishment of highest ranking officers and officials who are watching the competitions: "General Mendoza up there, and the ambassador, and the colonel" (p. 67). The unforeseeable triumph of the inferior rank over the superior tremendously vexes all the officers. More importantly, the disintegration of the big Circle culminates in the formation of smaller, albeit more resilient, packs which I explore, in the next section, with regard to their fascist sentiments.

\section{MICROFASCISM}

The State army and its inherent mass multiplicity enforce the contours of appropriate demeanour and thought on the students in Leoncio Prado. Conversely, the formation of smaller packs and the production of molecular becomings enkindle the emergence of a particular mode of brutality that is inherent to war machines as well as to fascist regimes. To investigate this emergent mode of interaction between packs and the military, I intend to draw on a particular conception of fascism. Whether defined as a primitive, anti-liberal "movement of mass-men" (Ortega y Gasset, 1932, p. 122) or as "the incorporation of the society into the state" with one political party above all other parties (Arendt, 1976, p. 258), fascism, without doubt, has remained one of the most obscure terms in political terminology. It is associated with despotism, militant violence, and oppression and is often employed as a pejorative epithet to denigrate a political opponent. Conceived of as the body of policies for the repression of dissenting voices, the term can be applied, for instance, to all communist regimes. This overdetermination has diminished the utility of this term. Others, conversely, restrict the contours of fascism to Italy and to Benito Mussolini's movement and regime. The term is also suggested to be employed as a generic category with analytic and heuristic purposes. In this sense, one has to probe the generalities of this notion rather than its specificities within particular geographies or movements. Hence, besides explaining the term negatively as anticonservatism, anti-Marxism, or anti-liberalism, one can conceive of fascism as a populist totalitarian system with a vanguard party and an ultranationalist agenda (Payne, 1995, pp. 3$5)$.

From a yet different perspective, fascism is a specific form of desire mixed with action rather than a method of governance or administration. This problematizes its political classification. Fascism is not exclusive to the state apparatus, political parties, or other 
macropolitical segments within a nation state. It is a micropolitics, acting as a cancerous cell infecting and overwhelming every other cell in a society. It manifests itself not only in the masses as the fascism of the Left or of the Right, but also in smaller groupings and communities as the fascism in a neighbourhood, in a school, in a family, in a couple, in an individual. Fascism differs from totalitarianism. A totalitarian state is rigid and symptomatically conservative, invariably striving for its centralization and stability to ensure its permanencea political strategy that can be found in many dictatorial and even military regimes. Conversely, a fascist state is perniciously fluid, interminably in motion, always radiating and propagating its revolutionary fervour in every direction. It is suffused with a passion for annihilation. It is inherently a suicidal war machine which, once triggered, nurtures the nihilistic illusion that its perpetuity and further proliferation resides in the death and destruction of its enemies and even of itself. It legitimizes, in the name of a cause, the utter consumption and obliteration of the entirety of its resources, its people, its loyal servants (Deleuze \& Guattari, 1987).

Fascism, moreover, has close affinity with one's conception of truth and vengeance. A fascist is suffused with a sense of retaliation and possesses an unflinching belief in the superiority of his values and his construal of good and truth. He conceives of himself as the one who "sees in life an evil, a fault which is to be atoned for" (Deleuze, 1989, p. 137). To some measure, one can argue that fascist groups and, in specific, microfascist packs function to intensify the repressiveness of a dominant system, as they sometimes target those individuals who have refused "to play the game of repression" under an already oppressive regime (Guattari, 2016, p. 78). Hence, as microfascism tends to interfere with every dimension of the individuals and people's quotidian life, it may manifest itself, for instance, in vigilantism that functions as an informal mode of policing a society either in defiance of governmental institutions or in partial compliance with the State's surveillance and disciplinary apparatuses (Mareš \& Bjørgo, 2019, pp. 8-9). Finally, what makes microfascisms more dangerous than fascism is that fascist regimes, with all their dark devastating energies, result from the empowerment and growth of microfascist cells; "microfascisms have a specificity of their own that can crystallize into a macrofascism" (Deleuze \& Guattari, 1987, p. 228).

The most striking event in The Time of the Hero is the inception of a vigorous microfascist pack, with cadet Boa claiming that this is the small Circle which is "really running things" in the academy (Vargas Llosa, 2004, p. 57). The disintegration of the big Circle into smaller packs fosters the upsurge of microfascist sentiments. In other words, by his apparently judicious dismantling of the big Circle to guarantee order and mass multiplicity within the academy, lieutenant Gamboa inadvertently triggers the formation of a powerful fascist-type gang that not only is in command of Section One and beyond, but simultaneously exacerbates the repressiveness of the academy. The formation of the small Circle is ensued by the emergence of a multi-layered paradox. The military administration unknowingly encourages the formation of pack multiplicities with unpredictable war machine propensities. The disintegration of the big Circle, as a pack, does not contribute to its assimilation into the mass multiplicity of the academy but rather to its further radicalization with almost zero tolerance for any betrayal or non-conformity. These are, in general, the microfascist cells that lay down the law in Leoncio Prado.

Education at prestigious Leoncio Prado is typically appraised as an invaluable opportunity "to become a man" (Vargas Llosa, 2004, p. 309); it is a workshop to mould "a real man" (p. 330). Overlooked, on the contrary, are the groupings and frictions within the academy as well as the resuscitation of war machine proclivities that contest the organizational perceptions toward discipline, manhood, respect, or authentic identity. In this regard, Jaguar has centrality in the formation of a microfascist pack in Leoncio Prado. He is a "devil" (p. 149) and "an animal" (p. 150); a sinister character whose "laugh even frightens the rats" (p. 349). He is both a thief and a trustworthy comrade who "doesn't believe in anything" and yet he does 
not tolerate any profane language against "Saint Rosa" (p. 149). Jaguar is the embodiment of exceptional talents both as a loner and as a charismatic hero who can effectively assume the leadership of the new pack. The relation between Jaguar and the formation of the new Circle is noteworthy. Unlike the original Circle that includes all the cadets in Section One and aims to defend them against the harassment of higher-ranking cadets, the new Circle is comprised of a few individuals and operates as a coercive and intimidating clique, with its membership entailing its own initiation rites. To become a member of the new Circle, Cava has to fight Boa to demonstrate his trustworthiness. Shortly after Cava's admittance to the group, the members of the new pack succeed to neutralize the intimidation of the Fifth Year cadets. Despite being injured and bruised by their opponents, the new group is imbued with an aura of superiority, with Jaguar conceiving of this fearless defiance as "initiation for the new Circle" (p. 221).

Whereas the betrayal of one's friends and peers is possible and even encouraged within a mass multiplicity, a treasonous act against the members of a pack is almost inconceivable. Cava, as a member of the new Circle, steals the upcoming exam questions and assumes full responsibility for the theft without disclosing the names of his friends. He eventually exposes himself to the humiliating procedure of expulsion from the academy. To the cadets outside the new Circle, Cava's discharge marks the termination of a neutral friendship with a peasant cadet who irrationally determines to remain, for the rest of his life, "a stupid field hand" (Vargas Llosa, 2004, p. 200). Conversely, Cava's arrest and humiliation generates new missions for the remaining members of the new Circle. Upon Cava's arrest, Jaguar utters a menace against the covert betrayers: "they don't know who they're messing with" (p. 160); and during Cava's dismissal ceremony, Boa avows, "the [new] Circle's still here to get even for you" (p. 203). The death of Ricardo, too, cannot eliminate the pack multiplicity created by him and Alberto who threatens, albeit exaggeratedly, to "kill" any cadet that "cracks another joke" about the deceased cadet (p. 239). Alberto's fierce defence engenders a sombre ambience of bereavement in the barracks, with "no more joking, no more snarling, no more filth" (p. 239). To get revenge, Alberto eventually accuses Jaguar of murder and discloses the details of almost each and every prohibited activity committed by the new Circle and by the other cadets "in the barracks" ( $\mathrm{p}$. 322). In other words, Alberto is determined to deprive all cadets, including himself, of the possibility of any transgression of, or even freedom from, the repressive codes of the academy.

The new Circle is engaged in a series of illegal activities, including hazing, stealing and selling of uniforms and exam questions as well as distributing alcoholics and cigarettes among the cadets. On the surface, the new Circle operates as a gang of juvenile delinquents. From a different perspective, it functions as a microfascist group with suicidal sentiments. With microfascism concisely implying a "process by which the energy of mass desire is directed towards self-destruction" (Gandesha, 2020, p. 18), the small Circle can rightly be considered as a self-destructive pack. Unlike Cava and his two friends Boa and Curly who submit to their fates and failures in the academy, Jaguar repeatedly threatens his friends with annihilation. He swears, "If I get screwed, everybody gets screwed" (Vargas Llosa, 2004, p. 270), and intimidates them by averring, "You're in this as deep as I am" (p. 271). Whereas Cava surrenders to disciplinary measures of the academy without betraying his friends, Jaguar's personal devastation or being betrayed is supposedly calamitous to those within his pack and even to those outside the new Circle. In the wake of Ricardo's death, Jaguar menacingly anticipates that there would be "some other deaths in the section" before graduation from the academy (p. 270). The Circle, which initially functions as a line of dissidence against the unidirectional voice of military authority, gradually morphs into a ruthless cell, revealing its fascist and reactionary tendency against any form of polyvocality, dissent, or line of escape.

In the formation of a microfascist cell within the academy, one can discern the emergence of a subtle yet salient conflict between two opposing economies: the economy of a war machine growing within the economy of a State army. The former pertains to the new 
Circle with a tendency for total devastation. Throughout time, for instance, annihilation and the prescience of "more deaths" (Vargas Llosa, 2004, p. 270) become inherent to the purpose of the cell and its leader Jaguar who argues, "All the squealers ought to be dead" (p. 336). Not only does he conceive of Ricardo's death as "a good thing” (p. 336), but he also justifies his murder and claims that by shooting Ricardo from behind he only meant to "get revenge for the section" (p. 358), trying to "rid them" of a despicable character (p. 357). The latter economy pertains to the State army and Leoncio Prado. Gamboa, "the strictest of the officers" (p. 357), explains that the army's "economy" is one of circumventing "any useless deaths" (p. 358). According to this economic doctrine, the "responsible soldier" does not shoot an adversary that "lays down his arms and surrenders" (pp. 358-9). To put this another way, The Time of the Hero depicts how a microfascist economy crystalizes within a totalitarian economy.

Once recognized by his two nicknames, "the Judge" and "the Whip" (Vargas Llosa, 2004, p. 344), Lieutenant Gamboa conceives of "order and discipline" as "indispensable instruments of a rational collective life" (p. 344). Nonetheless, the lawless behaviour of the cadets under his command is a complication that suffuses Gamboa with "doubts" about the efficacy of his adherence to discipline and military regulations (p. 344). He is thoroughly appalled by his "blind faith in authority" (p. 345). What, in actuality, triggers Gamboa's dubiety and astonishment is that Leoncio Prado, a regularized organization with a commonsensical conception of being and approved military identity, has revivified war machine intensities and becomings along unpredictable trajectories. The rise of pornographic writer and poet Alberto as well as the growth of lawless yet talented packs with their own tenets, perceptions and even murderous frenzies are only a few of these lines of escape. Pack multiplicities and mass multiplicities, as such, dictate two disparate sets of codes and instructions within Leoncio Prado: the codes of discipline and manhood imposed by the military staff, on the one hand, and the manner individuals like Jaguar intend to instruct the cadets "how to be men," on the other (p. 349).

The Time of the Hero is often assumed to represent a microcosmic depiction of Peruvian politics par excellence. This can be inferred, for instance, from the allusions to obese Colonel Mendoza in the novel, who actually founded Leoncio Prado in 1943 and served as the Minister of Education for General Manuel Odría, the dictator of Peru (Oviedo, 1978, p. 20). It is also remarkable to emphasize that along with the entrenchment of an Italian-type fascism in Europe, "fascist movements had the greatest political and electoral success" in countries like Peru and Brazil during the 1930s (Pinto, 2020, p. 20). Hence, one may rightly argue that Vargas Llosa's visualization of the academy is a retrospective depiction of fascism in Peru or, alternatively, a work more "prescient" of the rise of "neofascist military regimes" that emerged in Latin America shortly after the publication of the book (Martin, 2012, p. 26). Despite such claims that may judiciously highlight the relation and relevance of the novel to its immediate geographical context and contemporary history, I contend that the political paradoxes of the novel have much broader implications. For the violent tension between the war machine and the State army are entrenched in the history of the State apparatus and the state military. This induces us to conceive of the novel as a plausible delineation of any war machine or microfascist cell that attains a suitable ground for its formation and proliferation within an institution as rigid and as regularized as a military academy.

\section{CONCLUSION}

The paradox of military man, in The Time of the Hero, is a multifaceted event. To some measure, it results from the institutionalization of a war machine which is originally extrinsic to the State apparatus and even detrimental to its stability and functions. In other words, the 
cadets, as the embodiment of a new subversive war machine, are within a school with a military administration, itself an institutionalized war machine. The novel, in particular, portrays a series of tensions between a group of cadets that experience becoming-animal and becomingwar machine, on the one hand, and the military administration that strives to systematize the life and identity of the cadets, on the other. More fundamentally, and, from an ontological perspective, the paradox of military man can also be attributed to two modes of existence corresponding to two conflicting modes of thought. This implies an opposition between a commonsensical conception of being and the affirmation of becoming. The former is propagated and enforced by the administrative insistence on military codes of behaviour and identification and by the frequent resort to a variety of disciplinary measures, including confinement, denunciation of packs, expulsion, and, in a word, the suppression of lines of flight and dissidence. The latter emerges as the consequence of hazing, gratuitous punishment, initiation and the enforcement of a culture of submission to authority.

The two modes of existence and thought also correspond to the simultaneous operations of two multiplicities in the academy. Hence, the paradox of military man can be explained in regard to the emergence of packs within the mass multiplicity of the academy. The inherent formation of pack multiplicities is highly striking, since they are accompanied by their own perceptions, allegiances, conceptions of truth, and war machine tendencies with some measure of microfascist desire for annihilation. An analogous paradox is also discernible in the relation between two antithetical economies within the academy: the economy of a war machine versus the economy of a State army, or, the economy of excess with a fascist zeal for destruction versus the economy of prudence to avoid unnecessary loss of lives. To ensure the sustainability of its mass multiplicity, the military administration tends to suppress pack multiplicities; this is sometimes achieved by enforcing the cadets to either endure punishment for what they have not committed or opt for the betrayal of their peers. Unity and esprit de corps are only encouraged and promoted insofar as they do not impair the hierarchical structure of administration. The dismantling of the Circle culminates in the formation of a microfascist cell with determination for revenge and retaliation. Whereas the expulsion or death of a cadet within a mass multiplicity is considered a matter of quantitative reduction, the occurrence of a similar event within a pack multiplicity may trigger vengeance, regardless of its scope of devastation even for the entire members of the group.

\section{REFERENCES}

Alosman, M. I. M. \& Raihanah, M. M. (2020). Survival Psychology in Kevin Powers' The Yellow Birds. GEMA Online® Journal of Language Studies Vol. 20 (1), 139-150. http://doi.org/10.17576/gema-2020-2001-09.

Arendt, H. (1976). The Origins of Totalitarianism. San Diego: Harcourt Brace.

Caforio, G. (2009). Rhetorical Persuasion and Storytelling in the Military. In Kümmel, G., Caforio, G. \& Dandeker, C. (Eds.). Armed Forces, Soldiers and Civil-Military Relations: Essays in Honor of Jürgen Kuhlmann (pp. 89-100). Wiesbaden: VS Verlag für Sozialwissenschaften.

Castro-Klarén, S. (1990). Understanding Mario Vargas Llosa. Columbia: University of South Carolina Press.

Deleuze, G. (1989). Cinema 2: The Time-Image. (H. Tomlinson \& R. Galeta, Trans.). Minneapolis: University of Minnesota Press.

Deleuze, G. (1990). Logic of Sense. (M. Lester \& C. Stivale, Trans.). New York: Columbia University Press.

Deleuze, G. (1994). Difference and Repetition. (P. Patton, Trans.). New York: Columbia University Press.

Deleuze, G. (1995). Negotiations, 1972-1990. (M. Joughin, Trans.). New York: Columbia University Press.

Deleuze, G. \& Guattari, F. (1987). A Thousand Plateaus: Capitalism and Schizophrenia. (B. Massumi, Trans.). Minneapolis: University of Minnesota Press.

Deleuze, G. \& Parnet, C. (2007). Dialogues II. (H. Tomlinson \& B. Habberjam, Trans.). New York: Columbia University Press.

Digby, T. (2014). Love and War: How Militarism Shapes Sexuality and Romance. New York: Columbia University Press.

Eliade, M. (1958). Rites and Symbols of Initiation: The Mysteries of Birth and Rebirth. (W. R. Trask, Trans.). New York: Harper Colophon Books. 
Gandesha, S. (2020). Introduction. In Samir Gandesha (Ed.). Spectres of Fascism: Historical, Theoretical and International Perspectives (pp. 1-24). London: Pluto Press.

Gonzalez-Cueva, E. (2000). Conscription and Violence in Peru. Latin American Perspectives. Vol. 27 (3), 88-102. www.jstor.org/stable/2634082.

Guattari, F. (2011). The Machinic Unconscious: Essays in Schizoanalysis. (T. Adkins, Trans.). Los Angeles: Semiotext(e).

Guattari, F. (2016). Lines of Flight: For another World of Possibilities. (G. Andrew, Trans.). London: Bloomsbury Academic.

Hart, S. M. (2007). A Companion to Latin American Literature. Woodbridge: Tamesis.

Khoo, M. G. H. \& Abdul Hamid, B. (2019). Power Structures and Patterns of Interaction in the Malaysian Army. 3L: The Southeast Asian Journal of English Language Studies. Vol. 25(3), 46-64. http://doi.org/10.17576/3L-2019-2503-04.

Kristal, E. (1998). Temptation of the Word: The Novels of Mario Vargas Llosa. Nashville: Vanderbilt University Press.

Magnarelli, S. (1976). The Time of the Hero: Liberty Enslaved. Latin American Literary Review. Vol. 4 (8), 35 45. www.jstor.org/stable/20119006.

Mareš, M. \& Bjørgo, T. (2019). Vigilantism against Migrants and Minorities: Concepts and Goals of Current Research. In M. Mareš and T. Bjørgo (Eds.), Vigilantism against Migrants and Minorities (pp. 1-30). London: Routledge.

Martin, G. (2012). The Early Novels: The Time of the Hero and The Green House. In Kristal, E. \& King, J. (Eds.). The Cambridge Companion to Vargas Llosa (pp. 22-36). Cambridge: Cambridge University Press.

Moraña, M. (2016). Arguedas / Vargas Llosa: Dilemmas and Assemblages (A. Ascherl, Trans.). St. Louis, MO: Palgrave Macmillan.

Nunn, F. M. (1987). Mendacious Inventions, Veracious Perceptions: The Peruvian Reality of Vargas Llosa's La ciudad y los perros. The Americas. Vol. 43 (4), 453-66. www.jstor.org/stable/1007189.

Ocasio, R. (2004). Literature of Latin America. Westport, CT: Greenwood Press.

Ortega y Gasset, J. (1932). The Revolt of the Masses. New York: W. W. Norton.

Oviedo, J. M. (1978). The Theme of the Traitor and the Hero: On Vargas Llosa's Intellectuals and the Military. World Literature Today. Vol. 52 (1), pp. 16-24. www.jstor.org/stable/40133911.

Payne, S. G. (1995). A History of Fascism 1914-1945. Wisconsin: University of Wisconsin Press.

Pinto, A. C. (2020). Latin American Dictatorships in the Era of Fascism: The Corporatist Wave. London: Routledge.

Thornhill, T. (1982). The Earlier Novels of Mario Vargas Llosa. The Crane Bag. Vol. 6 (2), 102-5. www.jstor.org/stable/30023912.

Vargas Llosa, M. (2004). The Time of the Hero. (L. Kemp, Trans.). London: Faber \& Faber.

Williams, R. L. (2014). Mario Vargas Llosa: A Life of Writing. Austin: University of Texas Press.

Zandy Ali Pinak, M. \& Lalbakhsh, P. (2019). Orientalism on the Margins: Inter-Subjective Space in Edward Granville Browne's A Year amongst the Persians. 3L: The Southeast Asian Journal of English Language Studies Vol. 25(3), 33-45. http://doi.org/10.17576/3L-2019-2503-03. 